\title{
Human Rights Concerns in Indonesia's Counterterrorism Policies: The Emergence of a Domestic Security Dilemma in Indonesia's Densus 88 Security Posture
}

\author{
Bama Andika Putra \\ Department of International Relations, \\ Universitas Hasanuddin, Indonesia; \\ Melbourne School of Government, \\ University of Melbourne, Australia
}

DOI: https://doi.org/10.36941/ajis-2020-0125

\begin{abstract}
The counterterrorism policies of Indonesia have led the community to perceive the government as both protectors of human rights, but fear possible oppressions at the same time. The recorded figures of human rights violations, including extrajudicial killings, torture, and the dismissal of legal rights for individuals suspected as terrorists, have led to the construction of fear and insecurity among the Indonesian people of the state's approach to counterterrorism. Employing the concept of 'Domestic Security Dilemma' developed by Field in 2016, this article argues that; (1) Detachment 88's coercive methods in counterterrorism have led to human rights oppression and the construction of fear and insecurity among Indonesian citizens, and (2) the emergence of a 'Domestic Security Dilemma' due to the growing discourse of Detachment 88's dismissal initiated by individuals and Islamic community organization in Indonesia.
\end{abstract}

Keywords: Counterterrorism, Human Rights, Domestic Security Dilemma, Indonesia, Terrorism

\section{Introduction}

The formation of Indonesia's Detachment 88 (Densus 88) is inseparable to the US counterterrorism efforts in Southeast Asia. Defined as the second front of the war on terrorism, George W. Bush in the period of 2001-2011 looked beyond the Middle East for potential areas of terrorism concern (Gede Wahyu Wicaksana, 2019; Kreiman \& Espadafor, 2019). In the case of Southeast Asia, the presence of indigenous radical Islamist groups since decades ago and rooted from the war in Afghanistan in the 1980 s have led to the proliferation of radical ideology in Southeast Asia (Kluch \& Vaux, 2016; Magouirk, Atran, \& Sageman, 2008). In an effort to counter the possibilities, the US through its US Office of AntiTerrorism Assistance Bureau of Diplomatic Security initiated financial and technical support for Southeast Asian states to counterterrorism (Koruts, 2020). In Indonesia, the group formed because of the cooperation with the US is Indonesia's Densus 88 (Rucktäschel \& Schuck, 2019; Smith, 2005). Formally established on 20 June 2003, the anti-terrorism group consisted of Indonesia's elite police officers tasked with the operation of counterterrorism in Indonesia. Along with the National Agency for Combating Terrorism (BNPT), counterterrorism measures in Indonesia are then categorized into persuasive and coercive countermeasures, persuasive defined as deradicalization programs, and coercive meaning capturing of potential suspects (Agastia, Perwita, \& Subedi, 2020). 
In the conduct of both persuasive and coercive counter-terrorism measures, Densus 88 initially faced much public support due to their success. Cases of terrorism in the early 2000 in Indonesia were majorly focused on the terrorist group of Jemaah Islamiyah (JI), which is rooted in the 1940s Darul Islam (Meliala, 2015; Mubarok \& Hamid, 2018). Due to fundamental disagreements among JI members, members embracing hardliner JI ideology had a coercive vision for JI, leading it to affiliate themselves with terrorist organizations such as Al-Qaeda. Since then, a list of terrorist attacks has emerged, with notable cases in the 2002 and 2005 Bali bombings, 2003 and 2009 JW Marriott Hotel bombings, and the 2004 Australian Embassy bombing (Fair \& Shepherd, 2006; McCauley \& Scheckter, 2008). Densus 88 was able to respond efficiently, with the capturing of JI's key figures, which include Noordin M Top (2009), Umar Patek \& Dumaltin (2010), Abu Dujana (2007), and Azhari Husin (2005), all suspected in taking part in Indonesia's terrorist threats (Oak, 2010; Zakiyah, 2016). The discourse of Densus 88 was its capacity to relieve Indonesia from the horrors of past terrorist attacks. However, starting from the early 2010 , the discourses have dramatically shifted to one that has constructed fear among Indonesian citizens, due to the allegations of human rights violations, extrajudicial killings, torture as an interrogation method, extraordinary renditions, and no access to plead not guilty in the face of the judicial system (Istiqomah, 2015).

The constructed discourse has thus faced a major shift in regards to the citizen's perception of Densus 88. A prevalent discourse is the possible dismissal of Densus 88 due to the human rights violations it has created. There seems to be a growing fear and insecurity, especially embraced by the approximately 220 million Muslim citizens of Indonesia, stating that anyone can be captured because of their Islamic religion. In understanding this shift of paradigm towards Densus 88, this article employs the concept of security dilemma that is usually utilized to understand study cases among state actors. But this study will specifically focus on the growing discourse of the 'domestication' of the security dilemma, known as 'Domestic Security Dilemma,' developed by Antony Field in 2016. It argues how the intention to protect citizens through counterterrorism measures have led to fear of oppression among the community.

\section{Literature Review}

The concept of security dilemma initially was introduced in the 1950 os by John Herz and Herbert Butterfield. They aimed to highlight circumstances in which a state's effort to enhance the security led to counterproductive outcomes. Specifically, in the article of Herz, he stated how state behavior is influenced by fear and security, leading them to embrace a policy that maximizes power for self-defense purposes (Herz, 1950). Unfortunately, such actions provoke other state actors to undertake a similar route of policies, leading to a certain security dilemma. Butterfield on the other hand focused on the idea of perception, and how relations among countries are well complexified by the idea of suspiciousness and mistrust that is present (Tang, 2009). It was clear that both Herz and Butterfield aimed their arguments towards state actors, but they did not neglect that this nature is present in both groups and individuals, as the condition to secure security is a permanent state of affairs in life.

Since the inception of the security dilemma in the 1950s, a number of scholars have dedicated their work to develop the discourse in the context of state-state relations. Robert (1978) attempted to argue how policies to advance the security of a state will lead to other states to undergo a similar path of policies. Jack Levy (2002)also argued how because states act to simultaneously advance their security capabilities, they eventually prepare themselves to the level of war preparation due to the emergence of the security dilemma. Besides the possibilities of war, Jack Snyder (1984)also highlighted the possibility of state actors to undergo arms competition due to the advancement of security capabilities among the mistrusted states. Due to the focus of militarization and mistrust, some scholars have claimed that the security dilemma concept thus positions anarchy as a central feature that leads to its occurrence (Taliaferro, 2004) (Tang, 2009). The literature on security dilemma thus has been dominated by this notion of advancing security capabilities, in facing uncertainties. But what is worthy to be noted in this discourse that there is a growing trend to see perceive the concept of security 
dilemma beyond the traditional lens of the international security dilemma. This trend has focused on the variable of social groups that exist in a state, extending the discourse to possibly analyze the emergence of a security dilemma in the context of asymmetrical conflicts such as ethnical and civil conflicts.

Referring back to Herz's argument on security dilemma, he mentioned the variable of domestic actors, and the possible relevance of bringing the concept of security dilemma to the context of individuals and groups (Herz, 1950). A justifiable reason for this possibility is that the concept of security dilemma focuses on the vulnerability of human beings, and how they are in nature insecure (Field, 2016). Therefore, making other variables such as individuals and groups within a state subjected to the possible emergence of the security dilemma. Having to exist in any social unit makes it possible thus to analyze the security relations between citizens and government stakeholders.

Antony Field in 2016 introduced the term Domestic Security Dilemma in an attempt to highlight the possibility of both domestic and international level use of the security dilemma. He provided a comprehensive understanding of how security issues such as terrorism have led state actors to implement certain coercive counterterrorism measures, aimed to heighten a state's security posture. He then highlighted that the core intention of a state to protect citizens through counterterrorism measures has led to the occurrence of a security dilemma, in which citizens feel insecure of the excessive power owned by their respective governments. To prove his point, he focused on the US counterterrorism policies and the security dilemma it led to among the US citizens (Field, 2016). This article aims to expand the discourse of the social units utilized in the concept of the security dilemma. It will focus on the emergence of a security dilemma in the context of Indonesian counterterrorism measures, by highlighting the forms of counterterrorism policies, and the fear it has constructed among the Indonesian population.

\section{Methodology}

This article is a qualitative research that focuses on answering why a domestic security dilemma has been constructed in Indonesia's counter-terrorism measures through Densus 88. In responding to the stated research question, this study will utilize both primary and secondary data related to counterterrorism efforts in Indonesia, with the time frame between 2003-2016. The year 2003 is justified due to counterterrorism laws, national bodies, and Densus 88 were constructed in that year, therefore, making it possible to analyze the occurring dynamics. Meanwhile, 2016 is chosen because discourses of counter-terrorism perception of the community majorly shifted between the years 2013-2016, making it ideal to analyze the significance of such dynamics. In this article, the author will conduct a deductive approach by developing the research question based on a specific theory defined to be most relevant in addressing the concerns of this research.

This article employs the concept of 'Domestic Security Dilemma,' coined by Antony Field in a 2016 article entitled 'The Dynamics of Terrorism and Counterterrorism: Understanding the Domestic Security Dilemma.' By definition, domestic security dilemma is referred to as government policies that are intended to safeguard citizens from certain threats, a concern grows over possible government oppressions. In the context of terrorism, it specifically covers the phenomena of how a government's intention to implement counter-terrorism measures to protect the citizens from terrorist attacks, lead to citizens to suspect possible misuse of the excessive power of their own government.

\section{Human Rights Oppression and the Construction of Fear and Insecurity among Indonesian Citizens}

The Indonesian counterterrorism approach can be categorized into persuasive and coercive methods. The persuasive method includes a number of policies implemented by the National Agency for Combating Terrorism (BNPT) related to educational programs and the deradicalization of former terrorists. Meanwhile, the coercive front is majorly executed by Densus 88, which focuses on 
countering terrorism in the field. A major discourse that has emerged among the citizens is the human rights oppressions that have been conducted since Densus 88's establishment in June 2003 (Haryadi, 2014; Muhtar, 2014; Solihin \& Heniarti, 2017; Takasili, 2015). It is worthy to note that the emergence of this discourse is detached to the success of Densus 88 in capturing key perpetrators of terrorist attacks in Indonesia, as it highlights cases in which Densus 88 has mistakenly captured individuals, the prevalence of extrajudicial killings, even to the presumed conduct of torture.

It is thus urgent to note that Densus 88 has been solid in eradicating major key figures of terrorists in Indonesia since 2003. In relation to members of the Jemaah Islamiyah, Densus 88 embraced a key role in the capturing of the suspects of the Bali bombings (2002, 2005), J.W. Marriott Hotel Jakarta bombings (2003, 2009), and the Australian Embassy (2004) (Bawole, 2014). The coercive front in countering terrorism in Indonesia is arguably justified to attain the level of success needed to permanently destabilize terrorism networks in Indonesia. However, the use of coercive methods is risky, as it possibly leads to fear and insecurity among the citizens that the state vows to protect. This is where this article perceives a high probability of a domestic security dilemma, considering the human rights oppressions related to counterterrorism policies implemented in Indonesia.

In general, there have been extensive studies that aim to expose the human rights concerns because of the operations conducted by Densus 88 . Bawole (2014) argued that the close to the unlimited authority given to Densus 88 has led to the conduct of human rights oppressions that have been prevalent since the establishment of the anti-terror group. Furthermore, concerns over the treatment of human rights have been studied earlier by Solihin (2017) Kusuma (2018), by providing extensive lists of possible human rights oppressions, and the possibility of them violating existing International human rights laws that have been ratified by Indonesia. There is thus a consensus on Densus 88 that it is inevitable to highlight the human rights oppressions conducted throughout their anti-terror operations, but it is arguably incorrect to state that they have not been effective in implementing their coercive methods in counterterrorism.

In the context of human rights oppressions, the emergence of this discourse can be traced to the reports published by the Indonesian Commission on Human Rights (Komnas HAM). It is reported that since the establishment of Densus 88 in 2003 until 2016, there have been approximately 123 casualties that have occurred due to the mishandling of the Densus 88 (Sari, 2016). The quantitive data on the human rights oppressions cannot speak alone, as it is the forms of mishandling that have constructed the discourse of how severe the methods implemented by Densus 88 . To list the allegations made, the forms of mishandlings that have been conducted include torture, inhumane treatments, the use of threats and fear, dismissal of legal rights, seizures of property, as well as extrajudicial killings. Due to the forms of human rights oppressions listed, it is relatively easy to conclude that it has thus constructed a certain discourse among the community, to fear the organization that vows to protect them. For example in the case of extrajudicial killings, despite public protests and demands for considering human rights, Densus 88 has launched larger-scale operations to accelerate efforts of a manhunt for suspected perpetrators of terrorism (Susetyo, 2018).

As it is evident that the human rights concerns over counterterrorism policies have constructed a sense of fear and instability among the Indonesian population, this concern is then critical to understanding the discourses of changing counterterrorism policies in Indonesia. As Field (2016) elaborates in the case of the US counterterrorism policy, the presence of human rights violations in the US counterterrorism policy has led to public protests and pressure to alter the form of policies to counter-terror. In the case of Abu Ghraib and Guantanamo Bay, the viral photos of suspected terrorists detained and treated inhumanely (tortured) have led to public criticisms, therefore leading to changes in counterterrorism policies (Turner, 2012; Wolfendale, 2007). The Patriot Act of 2001, which gives the right to the US government to monitor and tap personal lines to identify possible terrorism-related communication, has led community organizations to lead protests stating that the US government has violated the liberty of the US people. And last, the collateral damage (from both the US military and Afghanistan civilians) has led to the withdrawal of US forces in Afghanistan since 2016. What has led to these drastic changes in counterterrorism policies? In all of the cases, there have been human rights 
violations that occurred and sparked the discourse of changing existing counterterrorism policies due to the presence of human rights oppression. Similar to the argument of Field and the case of changes in the US counterterrorism policies, Indonesia faces a similar dynamic, as the emergence of human rights violations in Indonesia's counterterrorism policies has led mass protests that aim to expose the oppression, and the need to change Indonesia's approach to counterterrorism.

\section{Contextualizing the Emergence of a Domestic Security Dilemma due to Densus 88's Counterterrorism policies: Evolution of the Discourse}

Domestic security dilemma implies that attempts by the government to safeguard citizens from counterterrorism threats lead to a state of fear among citizens of possible government oppressions. This section will elaborate ton he forms of government counterterrorism policies through Densus 88 aimed to counter the threat of terrorism in Indonesia but has at the same time, constructed a sense of fear and instability. The output of this fear among the citizens lead to certain discourses aimed to reshape the forms of counterterrorism responses adopted by the government. In the case of the US, it has been prevalent that the internal disagreements among the citizens have led the US government to change its counterterrorism policies based on public opinion. A number of crucial changes include the abandonment of overseas extrajudicial capturing (Abu Ghraib and Guantanamo Bay), and the dynamics of employing and withdrawing troops from the centers of war on terrorism (Afghanistan and Iraq) (Field, 2016). The changes of the US counterterrorism response indicate a form of the domestic security dilemma, as the changes made are caused by a growing sense of fear among the US community of possible US oppression and civil rights violations targeted to normal citizens.

Unlike the counterterrorism policies of the US, the form of domestic security dilemma in Indonesia's counterterrorism policies does not take in the form of changes in policies, but in the form of growing discourses to alter existing policies. This is justified as a form of the domestic security dilemma, as the concept in itself focuses on the construction of fear and insecurity that leads to a certain dilemma in the social unit level of analysis. This section thus will focus on the forms of discourses that have been prevalent in the context of Indonesian counterterrorism policies over the years, which relates to suggestions to dissolve existing efforts of counterterrorism including the utilization of Densus 88 as the main agent of capturing and investigating terrorism suspects.

Considering the previous section of allegations directed to Densus 88 pertaining to human rights violations, there have been growing demands by individuals, communities, as well as community and religious groups in Indonesia to dissolve Densus 88. One of the major events that have triggered this discourse is the capturing of an individual named Siyono on og March 2016, followed by news of his death 2 days later (Solihin \& Heniarti, 2017). Densus 88 confirmed that his death is due to his noncompliance during the course of his capturing and interrogation, leading him to be executed by the Indonesian anti-terror force. This phenomenon immediately sparked criticism and protests in the city of Solo, all demanding justice over the irregular death of Siyono (Budi R, 2016). The Indonesian National Commission on Human Rights estimates that in 2016 alone, approximately 100 individuals have been captured without a judicial hearing, with some shot to death without trial. The basis of Densus 88's actions throughout the years can be referenced to the National Law No.15 2003 on Combating the Criminal Act of Terrorism (Haryadi, 2014). It states that forces are eligible to conduct capturing with basic evidence attained from intelligence reports for a period of 7X24 hours. It is thus in 2016 in which the discourse of the Densus 88 dismissal has been well prevalent, solidifying the emergence of a discourse related to community fear of extrajudicial killings and unfair treatment of those suspected of terrorism.

But the formation of this discourse started in 2013 after a number of Islamic community organizations started vocalizing the human rights oppressions that have been prevalent. Most vocal in constructing this discourse was the Majelis Ulama Indonesia (MUI), Muhammadiyah, and other Islamic community organizations (Kusuma, 2018). Several key oppressions highlighted were extrajudicial killings, torture, and the instilment of fear to other subjects of citizens besides terrorists (Nurdiansyah, 
2013). Most of the individuals captured include those suspected by Densus 88 as being involved in a terrorist act/ group, most if not all are of the Islamic religion. MUI and other Islamic community organizations stated that these capturing have instilled a psychological fear of embracing Islamic religion, as they can be captured at any time with the prime suspects of being involved in terrorist acts.

A question that arises then is whether the constructed discourse made by Islamic community organizations pose any significance or not. The religion of Islam is the dominant religion embraced by Indonesian citizens. Approximately 2/3 (220 million) citizens of Indonesia are practicing Muslims, that have followed the preachings and guidelines socialized by Islamic community organizations such as Muhammadiyah and MUI. It was very much evident that in 2013, the Islamic community organizations represented the voice of the Indonesian people, by constructing a certain negative identity of Densus 88 , leading to the discourse of the urgency to dismiss the organization in its entirety. The statements made though do not simply reflect the voices of Islamic communities only, as the National Commission for Human Rights (Komnas HAM) has also been vocal about the human rights violations committed under the name of counterterrorism (Haryadi, 2014). Komnas HAM has focused on the discourse to make drastic changes to the method of operation, rather than the overall dismissal of Densus 88 .

The presence of a discourse to dismiss Densus 88 because of human rights concerns provides proof of the emergence of a domestic security Dilemma. Densus 88 has been mandated by Indonesia to conduct counterterrorism measures against perpetrators of fear and terror in Indonesia, as well as to provide security towards the Indonesian people. However, during this process of empowering counterterrorism coercive measures to eradicate terrorism, the process has constructed a sense of fear, instability, and insecurity among the Indonesian citizens towards the national counterterrorism policies adopted. This has to lead to a certain dilemma among Indonesian policymakers, as to the proper counterterrorism policy that needs to be adopted, which can lead to a sense of security and instability for the people, rather than the opposite. In 2016, the Indonesian government introduced plans to further empower Densus 88 to maximize their capacity in countering terrorism in Indonesia. However, this proposition to revise the Terrorism National law led to protests and fears of an excelled human rights oppression in the future.

\section{Conclusion}

A domestic security dilemma has emerged in Indonesia's counterterrorism policy through Densus 88 . Despite the anti-terror force's mandate to protect the Indonesian citizens in the context of counterterrorism, there is a growing discourse that the very same policy has led to the construction of fear and insecurity among the Indonesian people. The emergence of this security dilemma can be attributed to the human rights violations conducted by Densus 88, including extrajudicial killings, torture, and having no access to legal rights. Such oppressions thus have led the society to perceive Densus 88 as a threat to the livelihood, leading to the development of new discourses related to the dismissal of the organization in 2013 and 2016. The discourses were led by Islamic community organizations, which represents the voices of approximately 225 million citizens and highlighting the fear that is present among the Indonesian population due to the operations conducted by Densus 88 throughout the years. The dynamics of support and protest towards Indonesia's counterterrorism policies is what Field in his 2016 article states as a domestic security dilemma, but in the case of counterterrorism in Indonesia, takes in the form of fear and insecurity, leading to the construction of a discourse to dissolve Densus 88 .

\section{References}

Agastia, I. G. B. D., Perwita, A. A. B., \& Subedi, D. B. (2020). Countering violent extremism through state-society partnerships: a case study of de-radicalisation programmes in Indonesia. Journal of Policing, Intelligence and Counter Terrorism, 15(1), 23-43. https://doi.org/10.108o/18335330.2020.1722317 
Bawole, M. S. (2014). Kewenangan Tim Densus 88 Dalam Penanggulangan Terorisme Di Indonesia 1 Oleh : Marshaal Semuel Bawole 2. Lex Et Societatis, 2(1). Retrieved from https://ejournal.unsrat.ac.id/index.php/lexetsocietatis/article/view/3983

Budi R, M. (2016, March 15). Protes Tewasnya Siyono, Ratusan Pemuda Solo Tuntut Pembubaran Densus 88. Retrieved July 26, 2020, from News.Detik website: https://news.detik.com/berita/d-3165414/protes-tewasnyasiyono-ratusan-pemuda-solo-tuntut-pembubaran-densus-88

Fair, C. C., \& Shepherd, B. (2006). Who supports terrorism? Evidence from fourteen Muslim countries. Studies in Conflict and Terrorism, 29(1), 51-74. https://doi.org/10.1080/10576100500351318

Field, A. (2016). The dynamics of terrorism and counterterrorism: Understanding the domestic security dilemma. Studies in Conflict and Terrorism, 40(6), 470-483. https://doi.org/10.1080/1057610X.2016.1221253

Gede Wahyu Wicaksana, I. (2019). Militarising counterterrorism in Southeast Asia: Incompatibilities and implications for ASEAN. European Journal of East Asian Studies, 18(2), $205-235$. https://doi.org/10.1163/15700615-01802005

Haryadi, D. (2014). Pemberantasan Terorisme Berorientasi Ham. MMH, 43(2).

Herz, J. H. (1950). Idealist Internationalism and the Security Dilemma. World Politics, 2(2), 157-18o.

Istiqomah, M. (2015). In the Name of Counter-Terrorism: Human Rights Abuses in Indonesia. Asia Pacififc Journal of Advanced Business and Social Studies, 1(1). Retrieved from www.apiar.org.au

Jervis, R. (1978). Cooperation under the security dilemma. World Politics, 30(2), 425-441. https://doi.org/10.2307/2009958

Kluch, S. P., \& Vaux, A. (2016). The non-random nature of terrorism: An exploration of where and how global trends of terrorism have developed over 40 years. Studies in Conflict and Terrorism, 39(12), 1031-1049. https://doi.org/10.1080/1057610X.2016.1159070

Koruts, U. (2020). International legal regulation of countering propaganda of war and manifestations of extremism. Academic Journal of Interdisciplinary Studies, 9(1), 105-114. https://doi.org/10.36941/ajis-2020-0oo9

Kreiman, G., \& Espadafor, M. C. (2019). Unexpected Allies: The Impact of Terrorism on Organised Crime in SubSaharan Africa and South-East Asia. Studies in Conflict and Terrorism. https://doi.org/10.1080/1057610X.2019.1678877

Kusuma, A. J. (2018). The Allegation of Human Rights Violation in the Process of Counter-Terrorism Acts in Indonesia by Densus 88 Force. Advanced Science Letters, 24(5), $3394-3398$. https://doi.org/10.1166/asl.2018.11384

Levy, J. S. (2002). Handbook of International Relations. https://doi.org/10.4135/978-1-8486o-829-o.n17

Magouirk, J., Atran, S., \& Sageman, M. (2008). Connecting terrorist networks. Studies in Conflict and Terrorism, 31(1), 1-16. https://doi.org/10.108o/10576100701759988

McCauley, C., \& Scheckter, S. (2008). What's special about u.s. muslims? The war on terrorism as seen by muslims in the united states, morocco, egypt, pakistan, and indonesia. Studies in Conflict and Terrorism, 31(11), 10241031. https://doi.org/10.1080/10576100802400193

Meliala, J. (2015). COUNTER-TERRORISM IN INDONESIA. Brawijaya Law Journal, 2(1), 54-73. https://doi.org/10.21776/ub.blj.2015.002.01.05

Mubarok, M. Z., \& Hamid, A. F. A. (2018). The Rise of Radicalism and Terrorism in Indonesia and Malaysia . Review of Islam in Southeast Asia, 1(1). Retrieved from http://103.229.202.71/index.php/risea/article/view/9645

Muhtar, Z. (2014). Eksistensi Densus 88: Analisis Evaluasi Dan Solusi Terkait Wacana Pembubaran Densus 88. Supremasi Hukum: Jurnal Kajian Ilmu Hukum, 3(1).

Nurdiansyah, R. (2013, March 4). Mabes Polri Tolak Pembubaran Densus 88 . Retrieved July 26, 2020, from Republika Online website: https://republika.co.id/berita/mj513t/mabes-polri-tolak-pembubaran-densus-88

Oak, G. S. (2010). Jemaah Islamiyah's Fifth Phase: The Many Faces of a Terrorist Group. Studies in Conflict and Terrorism, 33(11), 989-1018. https://doi.org/10.1080/1057610X.2010.514697

Rucktäschel, K., \& Schuck, C. (2019). An analysis of counterterrorism measures taken by Indonesia since the 2002 Bali bombings. The Pacific Review, 1-30. https://doi.org/10.1080/09512748.2019.1627485

Sari, E. N. (2016). Tim 13 Bentukan Komnas HAM Pantau Penanganan Terorisme oleh Pemerintah - Komnas HAM. Retrieved July 25, 2020, from KOMNAS HAM website: https://www.komnasham.go.id/index.php/news /2016/8/1/27/tim-13-bentukan-komnas-ham-pantau-penanganan-terorisme-oleh-pemerintah.html

Smith, A. L. (2005). The politics of negotiating the terrorist problem in Indonesia. Studies in Conflict and Terrorism, 28(1), 33-44. https://doi.org/10.1080/10576100590524311

Snyder, G. H. (1984). The Security Dilemma in Alliance Politics. World Politics, 36(4), 461-495. https://doi.org/10.2307/2010183 
Solihin, F. S., \& Heniarti, D. D. (2017). Handling of Criminal Measure of Terrorism by Densus 88 in The Perspective of Human Rights. Prosiding Ilmu Hukum; Vol 3, No 2, Prosiding Ilmu Hukum (Agustus, 2017 ); 817-823. Retrieved from http://repository.unisba.ac.id:8o8o/xmlui/handle/123456789/20720

Susetyo, H. (2018, October). Counter Terrorism and Human Rights Violation in the Aftermath of Terrorism in Indonesia. In Hukum Pidana Dan Pembangunan Hukum. Retrieved from http://www.state.gov/j/inl/rls/nrcrpt/index.htm

Takasili, N. (2015). Penanggulangan Tindak Pidana Terorisme Menurut Hukum Positif Indonesia 1 Oleh: Novian Takasili 2. LEX CRIMEN, 4(8). Retrieved from http://densus88-antiteror.blogspot.co.id/,

Taliaferro, J. W. (2004). Balancing Risks: Great Power Intervention in the Periphery. https://doi.org/10.7591/J.CTVV414NR

Tang, S. (2009). The Security Dilemma: A Conceptual Analysis. Security Studies, 18(3), 587-623. https://doi.org/10.108o/09636410903133050

Turner, I. (2012). Human rights and antiterrorism: A positive legal duty to infringe freedom from torture? Studies in Conflict and Terrorism, 35(11), 760-778. https://doi.org/10.1080/1057610X.2012.720237

Wolfendale, J. (2007). Terrorism, security, and the threat of counterterrorism. Studies in Conflict and Terrorism, 3o(1), 75-92. https://doi.org/10.1080/10576100600791231

Zakiyah, Z. (2016). The Chronicle of Terrorism and Islamic Militancy in Indonesia. Analisa, 1(1), 19. https://doi.org/10.18784/analisa.v1i1.276 